\title{
Technical Note: A High-Resolution Autonomous Record of Ice Nuclei Concentrations for Fall and Winter at Storm Peak Laboratory
}

Anna L. Hodshire ${ }^{1}$, Ezra J. T. Levin¹, A. Gannet Hallar ${ }^{2}$, Christopher N. Rapp ${ }^{3}$, Dan R. Gilchrist ${ }^{2}$, Ian

$5 \quad$ McCubbin $^{2}$, Gavin R. McMeeking ${ }^{1}$

${ }^{1}$ Handix Scientific Inc., Fort Collins, CO, 80526, USA

${ }^{2}$ Department of Atmospheric Sciences, University of Utah, Salt Lake City, UT, 84112, USA

${ }^{3}$ Department of Earth, Atmospheric, and Planetary Sciences, Purdue University, West Lafayette, IN, 47907, USA

10

Correspondence to: Anna L. Hodshire (anna@handixscientific.com)

15 Abstract. High-resolution, long-term measurements of ice nucleating particles (INPs) have been impeded by complex instrumentation that requires a trained on-site technician to operate or analyze offline. We have significantly updated the well-characterized continuous flow diffusion chamber (CFDC) instrument to run autonomously with minimal in-person handling and easy remote access. This new CFDC, the CFDC-Ice Activation Spectrometer (CFDC-IAS) was deployed for four months (October 2020-January 2021) at the mountain-top Storm Peak Laboratory site in Colorado and provided 5minute resolution measurements daily at target temperatures of $-20,-25$, and $-30{ }^{\circ} \mathrm{C}$. Concentrations of INPs across all temperatures had a median value of 6 per standard liter $\left(\mathrm{sL}^{-1}\right)$, and a mean of $10 \mathrm{sL}^{-1}$ with a range of $\sim 0-470 \mathrm{sL}^{-1}$.

\section{Introduction}

Ice nucleating particles (INPs) have significant impacts on mixed-phase clouds through altering of precipitation processes and radiative properties (DeMott et al., 2010). High-resolution, long-term measurement records of INPs are currently scarce due to the difficulty of making INP measurements. Unlike measurements of some other important aerosol characteristics, such as composition ( $\underline{\mathrm{Ng} \text { et al., 2011) }}$ or cloud condensation nuclei (Schmale et al. 2018), real-time ambient INP measurement techniques typically require an experienced technician on-site, and usually only occur in the context of intensive field campaigns (Lacher et al., 2018). Current single-site, longer-term (one year or longer) continuous records of INP require off-line processing and typically have daily to weekly time resolutions (Schneider et al., 2021) or may only capture short periods of each day, such as an hour or a few hours (Schrod et al., 2020b; Müller, 1969a). As discussed in (Schrod et al., 2020b), many successful longer-term records of INP occurred in the 1950s-1970s (Soulage, 1966; Kline, 1963; Bigg and Miles, 1964; Bigg, 1973; Müller, 1969b). Limited understanding of how rapidly changing global emissions including anthropogenic sources may impact INP and associated radiative forcings (Schrod et al., 2020a; Boucher et al., 
35 2013) along with limited spatial and temporal resolution of INP globally points to the importance of more frequent INP measurements.

Here, we have deployed a new continuous flow diffusion chamber (CFDC), the Handix Scientific CFDC-Ice Activation Spectrometer (CFDC-IAS) for four months (October 2020-January 2021) at the mountaintop Storm Peak Laboratory (SPL) in Steamboat Springs, CO (3220 m above mean sea level). The CFDC-IAS is based on the well-characterized Colorado State University CFDC (DeMott et al., 2015; Rogers et al., 2001) but has undergone significant modifications to allow for automated and near-continuous operation. The four-month, high-resolution mountaintop time series is the first of its kind, and follows a successful month-long deployment in May-June 2018 of an earlier version of the CFDC-IAS in Beijing, China (Bi et al., 2019).

\section{2. Methods}

\subsection{Measurement location}

The Storm Peak Laboratory (SPL) (40.455 deg N, -106.744 deg W) is located near Steamboat Springs, CO at $3220 \mathrm{~m}$ above mean sea level. Steamboat Springs is located in the northwestern Colorado Rocky Mountains, and SPL is approximately $1150 \mathrm{~m}$ above and to the east of the town of Steamboat Springs and the Yampa Valley, an agriculture area (Borys and

50 Wetzel, 1997). SPL is located on a $70 \mathrm{~km}$-long north-south mountain barrier, oriented perpendicular to the prevailing westerly winds. The nearest large population center to the west of SPL is the Salt Lake Valley, approximately 270 miles away. The climate of SPL is alpine, just above tree line, with dominant vegetation of Engelmann spruce, aspen, grasses, and flowering plants (Amin et al., 2013, 2012). The majority of precipitation for the area falls as snow between November and May, leading to an annual average of 166.6 inches of snow (https://wrcc.dri.edu/cgi-bin/cliMAIN.pl?co7936). Air masses at

55 SPL generally transition between nightly free-troposphere and daily boundary layer air (Obrist et al. 2008). A number of long-term meteorological and atmospheric state instruments are located at SPL, with guest instruments such as the Handix CFDC-IAS able to make shorter-term measurements. Further details on SPL are found in Borys and Wetzel (1997).

\subsection{CFDC-IAS}

The Handix Continuous Flow Diffusion Chamber Ice Activation Spectrometer (CFDC-IAS) deployed at SPL builds upon

60 several decades of development of CFDC instruments for measuring ice nuclei concentrations. The CFDC-IAS is modeled after the well-characterized Colorado State University CFDC (Rogers et al. 2001; DeMott et al. 2015) with numerous updates to improve operability and automation. The basic design consists of a cylindrical chamber, with two concentric, icecovered walls that particles pass between in a laminar flow. Establishing a temperature difference between the colder (inner) and warmer (outer) walls in the upper region of the chamber leads to an approximately steady-state region of water vapor 65 and temperature. Any INPs that can activate at the conditional water vapor and temperature grow into ice crystals. The inner 
and outer walls of the lower region of the chamber are set to the same temperature to evaporate water droplets and wet aerosol while retaining the ice crystals from activated ice nuclei. The ice crystals are detected at the bottom of the chamber with an optical particle counter. Impactors upstream of the chamber have a $2.5 \mu \mathrm{m}$ size cut to remove large particles that could be incorrectly optically classified as ice crystals, so the CFDC-IAS is designed to measure INP less than $2.5 \mu \mathrm{m}$ in aerodynamic diameter.

To account for spurious ice crystal counts originating from chamber surface frost, the CFDC-IAS switched between sampling HEPA filtered air and ambient air in 5-minute intervals. We follow the statistical methods laid out in the supplemental material of (Barry et al., 2021) to correct sample concentrations for instrument background and to define confidence intervals for the data. The residence time for a particle in the chamber between the time that it activates to when it evaporates is nominally $5 \mathrm{~s}$, but studies indicate the aerosol lamina may broaden in similar instruments, leading to longer residence times (Garimella et al., 2016). The broadening of the lamina along with other factors lead to higher supersaturations required in the CFDC to agree with expansion cloud chamber measurements. An underestimate of a factor of 3 is found for CFDC measurements of mineral dust INPs at a water relative humidity of 105\% (DeMott et al., 2015). Here

80 we do not apply any correction factor to the SPL CFDC data, as there is currently a lack of measurements that bound the uncertainty under different sampling conditions, but note that a correction of a factor of three or higher could be appropriate. While this correction appears to be a large difference, it is well within general uncertainties of ice nuclei measurements (DeMott et al., 2017).

85 The first CFDC-IAS was deployed in Beijing, China for one month (Bi et al., 2019) and updates from the CSU CFDC design to improve operability and automation are thoroughly described in that manuscript. This CFDC-IAS instrument has incorporated further updates. Most significantly the column material was changed from copper to anodized aluminum, while keeping the internal dimensions identical. The previous copper column design required chemical treatment (ebonization) to make the surface wettable and ensure a smooth ice layer. This process was highly time consuming, requiring the entire

90 instrument to be disassembled yearly, and required use of caustic chemicals. The aluminum column does not require this treatment. To ensure that changing the column material did not alter the instrument's function, we compared the new column to the CSU-CFDC, which uses the copper design, and found good agreement between the two instruments for laboratory measurements (Figure 1).

95 At SPL, the CFDC-IAS sampled from the main aerosol inlet (Petersen et al., 2019). Sample air was drawn through two diffusion driers (Handix Scientific) filled with silica gel and molecular sieves, respectively, and then passed through a 2.5 um size cut impactor. The instrument was set to automatically melt the ice walls and then refreeze the walls after 4-6 hours of operation, as the instrument background begins to increase due to frost buildup on interior surfaces after several hours of operation, lowering the detection limit. Instrument background concentrations were on average less than $1 \mathrm{~L}^{-1}$ at STP 
100 (denoted sL) at the beginning of an operation period and steadily increased, occasionally reaching average concentrations of 2-12 $\mathrm{sL}^{-1}$. As INP concentrations decrease at warmer temperatures (fewer particles activate) and can be as low as $<1 \mathrm{sL}^{-1}$, we aligned the sampling temperatures to be sequentially at $-20,-25$, and $-30{ }^{\circ} \mathrm{C}$ in approximately 2-hour cycles with warmest temperatures occurring at the start (cleanest background) of each operation cycle. Measurements taken during instrument transition periods when temperatures and/or saturation conditions were unstable were omitted from this analysis. The instrument operated continuously from October 10 2020-January 29 2021, except for January 3-10 due to a lack of nitrogen gas availability at the laboratory, which is used during the icing process to ensure no water vapor enters the chamber. A technician visited the site weekly to change out desiccant in the diffusion driers and switch nitrogen tanks when necessary ( every three weeks). Other than these visits, the instrument operated unattended during the measurement period.

\subsection{Supporting measurements, calculations, and modeling}

110 SPL houses a number of meteorological and aerosol measurements that we use in this study. Meteorological data are hosted by the University of Utah MesoWest program (https://mesowest.utah.edu/), and include temperature, pressure, relative humidity, and wind speed and direction, all at 5-minute resolution. The wind direction was reported by cardinal direction (north, north-northeast, and so forth). A scanning mobility particle spectrometer (SMPS) measured aerosol from 10-350 nm at 5-minute resolution (Gannet Hallar et al., 2016) while an aerodynamic particle sizer (APS) measured aerosol from 0.55-20

$115 \mu \mathrm{m}$ at 5-minute resolution (Hallar et al., 2011). The SMPS and APS data were combined to calculate total aerosol surface area between $10 \mathrm{~nm}-2.5 \mu \mathrm{m}$, assuming spherical particles. As there was no overlap in size range, we used the full ranges of both instruments. The APS aerodynamic diameters were further converted to volumetric diameters following (DeCarlo et al., 2004). Particle surface area was used in calculating surface active site density, $\mathrm{n}_{\mathrm{s}}$, (Niemand et al., 2012; Connolly et al., 2009) found by dividing the INP concentrations $\left(\mathrm{n}_{\mathrm{INP}}(\mathrm{T})\right)$ by aerosol surface area $\left(\mathrm{S}_{\mathrm{tot}}\right)$ :

$120 n_{S}=n_{I N P}(T) * \frac{10^{9}}{\text { Stot }}$

With Stot in units of $\mu \mathrm{m}^{2}$ per unit volume of air, $\operatorname{nINP}_{\mathrm{IN}}(\mathrm{T})$ in units of $\mathrm{sL}^{-1}$ per unit volume of air, and $\mathrm{n}_{\mathrm{s}}$ in units of $\mathrm{m}^{-2}$.

We calculate 5-day back trajectories using the NOAA HYSPLIT on-line READY model (Stein et al., 2015; Draxler and Hess, 1998, 1997; Rolph et al., 2017), using 1-degree GDAS reanalysis meteorological data, starting each run at $500 \mathrm{~m}$ above model ground level.

\section{3. Results \& Discussion}

\subsection{Stability and performance of the CFDC-IAS}

The CFDC-IAS at SPL ran continuously between October 9, 2020 and January 29, 2021, except for January 3-10 (Figure 2). Most days the instrument was set to measurement cycles of target laminar temperatures of $-20,-25$, and $-30{ }^{\circ} \mathrm{C}$ (Figure 3 ). The instrument was able to reach the target temperatures within $0.3^{\circ} \mathrm{C}$ and the target water supersaturations within $3 \%$. 
130 During measurement cycles, the average difference between inner and outer wall temperatures were $\sim 15{ }^{\circ} \mathrm{C}$ (Figure 3 ). Twohour replenishment cycles to thaw and reice the chamber walls occurred every four to six hours, depending on the preset measurement cycle. Periodically, the instrument was set to run only at $-30{ }^{\circ} \mathrm{C}$ to better observe changes in INP concentrations without changing measurement conditions. All changes to the measurement cycles were done remotely.

\subsection{INP concentrations, comparisons to previous SPL and other mountaintop measurements, and parameterizations}

135 Concentrations of INPs had a median of $6 \mathrm{sL}^{-1}$ and mean of $10 \mathrm{sL}^{-1}$ across all temperature ranges $\left(-20,-25\right.$, and $\left.-30{ }^{\circ} \mathrm{C}\right)$ (Figure 2 and 4), but with large variation $\left(\sim 0-470 \mathrm{~L}^{-1}\right)$. Little difference in medians or interquartile ranges occurred for observations taken in cloud (observations at $>90 \% \mathrm{RH}$ ) versus out of cloud, or for observations taken during the day versus during the night (Figure S1). Nighttime has previously been characterized as a rough proxy for free tropospheric air masses at SPL due to the presence of lower water vapor, aerosol, ozone, and CO concentrations (Obrist et al., 2008). Snowfall

140 occurred at SPL on 35 of the 111-day measurement period, while winds came primarily from the west (Figure 2). Ambient temperature at SPL ranged from -22.5 to $14.5^{\circ} \mathrm{C}$ (mean $-6.8{ }^{\circ} \mathrm{C}$, median $-8{ }^{\circ} \mathrm{C}$ ) and ambient wind speed ranged from 0.7$55.3 \mathrm{mph}$ (mean $16.4 \mathrm{mph}$, median $15.9 \mathrm{mph}$ ). No strong correlation between snowfall, temperature, relative humidity, wind direction, or wind speed and INP concentrations were observed. Periodic high $\left(>50 \mathrm{sL}^{-1}\right)$ concentrations of INP followed periods of air parcels arriving from both surrounding arid regions and oceanic regions as determined by 5-day HYSPLIT back trajectories, including southeastern Wyoming, Nevada, Arizona, the Four Corners region, the Gulf of California, and the north Pacific (Figure S2). However, low concentrations of INP during the campaign were also observed to have similar back trajectories, including days before or after high INP event days (Figure S3), limiting our conclusions on the direct sources of INP to SPL.

Previous CFDC deployments to SPL found average INP concentrations between -5 and $-50{ }^{\circ} \mathrm{C}$ to be $1-10 \mathrm{sL}^{-1}$ for both

150 November 2001 and April-March 2004 (Richardson et al., 2007; DeMott et al., 2003), similar to our observations. However, of the ranges reported in these studies, our range of INP at SPL reached higher concentrations. Other high-elevation free tropospheric INP measurements also tend to fall within $<1-10 \mathrm{sL}^{-1}$, with some sites reaching $\sim 20-30 \mathrm{sL}^{-1}$ (Lacher et al., 2018). The discrepancy in maximum concentrations observed between our study and other SPL and high-elevation studies may be due to differences in sampling frequency and duration: our measurements provide better temporal coverage than

155 previous measurements at SPL, increasing the likelihood that we would be able to capture short-term, high-concentration events. Other factors that can lead to differences in observations from study to study include ambient conditions, such as precipitation and weather patterns as well as substantial increases in drought severity and locations across the Western U.S. between autumn of 2001 and autumn-winter of 2020-2021 (U.S. Drought Monitor, https://droughtmonitor.unl.edu/Maps/MapArchive.aspx).

160 Previous INP laboratory and field efforts have found relationships between total aerosol surface area or aerosol concentrations above $500 \mathrm{~nm}$ and INP concentrations for specific species of INP, such as dust (Niemand et al., 2012; DeMott 
et al., 2010,2015). Total aerosol surface area (calculated as the sum of surface areas from the APS and SMPS; Methods) and aerosol concentrations for the APS and SMPS are shown in Figure 2. The APS data represents the aerosol concentrations above $500 \mathrm{~nm}$ and can have an outsized influence on surface area, as larger particles can dominate aerosol surface area, when present. The APS counts were generally very low (1 or less). Periodic increases in APS counts were observed (Figure 2), generally during periods of winds between the west-southwest and the north-northeast (Figure 2). Surface active site density, $\mathrm{n}_{\mathrm{s}}$, (eq. 1) also referred to as ice-active surface site density, is the sites upon which ice can form per surface area of a specific INP type that are active at temperature $\mathrm{T}$. Currently, $\mathrm{n}_{\mathrm{s}}$ is only strictly valid for describing a single type of INP. We follow (Bi et al., 2019; Levin et al., 2019) in comparing our results to previous values of $\mathrm{n}_{\mathrm{s}}$ to further diagnose the type of

170 INPs that may have been present at SPL (Figure 4). Median values of $\mathrm{n}_{\mathrm{s}}$ were $4.5 \times 10^{7} \mathrm{~m}^{-2}, 5.8 \times 10^{7} \mathrm{~m}^{-2}$, and $5.8 \times 10^{7} \mathrm{~m}^{-2}$ for INP at $-20,-25$, and $-30{ }^{\circ} \mathrm{C}$. The median $\mathrm{n}_{\mathrm{s}}$ values more closely follow the fit to clean marine data found by (McCluskey et al., 2018) than the fit for dust INP found by (Ullrich et al., 2017). Our data also falls within $\mathrm{n}_{\mathrm{s}}$ ranges for some species of pollens (Murray et al., 2012). Less than $1 \%$ of calculated $\mathrm{n}_{\mathrm{s}}$ values reached above $10^{9} \mathrm{~m}^{-2}$. These higher values have been found to be indicative of dust, or mineral INPs (Murray et al., 2012), potentially indicating that INP during the winter at SPL are dominated by species other than dust or mineral particles.

We also calculate the parameterizations laid out in (Niemand et al., 2012; DeMott et al., 2010, 2015), hereon D10 and D15, that relate aerosol concentrations $>500 \mathrm{~nm}$ to INP concentrations as a function of activation temperature (Figure 5). D10 was constructed for "global" (unspeciated) INP while available coefficient values for D15 parameterization are applicable for mineral dusts. D10 was found in (Niemand et al., 2012; DeMott et al., 2010, 2015) to reduce variability in INP at a given temperature to less than a factor of 10 . While $86 \%$ of the predicted INP concentrations lie within the 1:10 and 10:1 lines (green dashed line, Figure 5), 13.8\% of data lie between the 1:10 and 1:100 lines (orange dot-dash line, Figure 5) and 0.2\% of data falls outside of the 1:100 line. Similarly, the D15 parameterization captures $70.4 \%$ of data within the 1:10 and 10:1 lines, with $19.7 \%$ falling between the 1:10 and 1:100 line and 9.9\% of data falling outside of the 1:100 line. In general, both parameterizations perform best for the coldest $\left(-30^{\circ} \mathrm{C}\right)$ data but tend to underpredict observed INP concentrations, similar to findings of (Bi et al., 2019).

\section{Conclusions}

The established Continuous Diffusion Flow Chamber (CFDC) has an excellent track record of providing high-resolution ice nucleating particle (INP) measurements but has traditionally required an on-site, trained technician to run. Significant automation updates to the CFDC design to create the CFDC-Ice Activation Spectrometer (CFDC-IAS) allow for near continuous operation with minimal user intervention. We have deployed the CFDC-IAS at Storm Peak Laboratory (SPL), a long-term, mountain measurement site in Steamboat Springs, Colorado, USA for four months (October 2020-January 2021) to gather a high-resolution dataset of INP. This public dataset may be of interest for model-measurement comparison. We cycled between target temperatures of $-20,-25$, and $-30{ }^{\circ} \mathrm{C}$ for each measurement period, achieving stable conditions throughout the campaign. Concentrations of INPs were typically around a median of $6 \mathrm{sL}^{-1}$, mean of $10 \mathrm{sL}^{-1}$ at all 
195 temperature ranges, similar to previous CFDC measurements at SPL taken during fall and spring of 2001 and 2004 , respectively (Richardson et al., 2007; DeMott et al., 2003). However, our measurements captured a higher range of INP ( 0$470 \mathrm{sL}^{-1}$ ) than these earlier campaigns. The higher temporal coverage of our measurements compared to the earlier campaigns increase our ability to capture short-term, high-concentration events. As well, there may be different transport patterns or ambient conditions between this and previous campaigns. Our deployment of the CFDC-IAS at SPL provides promise for its potential for future longer deployments to help build up much-needed long-term, high-resolution INP datasets.

\section{Data availability}

The CFDC-IAS data is available at https://handixscientific.synology.me:8115/fsdownload/HYkyi0dOM/External.

\section{Author contributions}

ALH performed the data analysis and wrote the manuscript with assistance from EJTL, GRM, AGH, and CNR. EJTL, GRM, DRG, IM, CNR, and AGH performed or oversaw SPL measurements used in this manuscript.

\section{Acknowledgements}

Development and deployment of the CFDC-IAS was supported in part by NASA SBIR Contract 80NSSC19C0166. The

NSF Atmospheric Chemistry Program provided support (Grant \# AGS-2025215).

\section{References}

Amin, H., Atkins, P. T., Russo, R. S., Brown, A. W., Sive, B., Hallar, A. G., and Huff Hartz, K. E.: Effect of bark beetle infestation on secondary organic aerosol precursor emissions, Environ. Sci. Technol., 46, 5696-5703, 2012.

Amin, H. S., Russo, R. S., Sive, B., Richard Hoebeke, E., Dodson, C., McCubbin, I. B., Gannet Hallar, A., and Huff Hartz,

215 K. E.: Monoterpene emissions from bark beetle infested Engelmann spruce trees, Atmos. Environ., 72, 130-133, 2013.

Barry, K. R., Hill, T. C. J., Levin, E. J. T., Twohy, C. H., Moore, K. A., Weller, Z. D., Toohey, D. W., Reeves, M., Campos, T., Geiss, R., Schill, G. P., Fischer, E. V., Kreidenweis, S. M., and DeMott, P. J.: Observations of ice nucleating particles in the free troposphere from western US wildfires, J. Geophys. Res., 126, https://doi.org/10.1029/2020jd033752, 2021.

Bigg, E. K.: Ice Nucleus Concentrations in Remote Areas, J. Atmos. Sci., 30, 1153-1157, 1973.

220 Bigg, E. K. and Miles, G. T.: The Results of Large-Scale Measurements of Natural Ice Nuclei, J. Atmos. Sci., 21, 396-403, 1964.

Bi, K., McMeeking, G. R., Ding, D. P., Levin, E. J. T., DeMott, P. J., Zhao, D. L., Wang, F., Liu, Q., Tian, P., Ma, X. C., Chen, Y. B., Huang, M. Y., Zhang, H. L., Gordon, T. D., and Chen, P.: Measurements of ice nucleating particles in Beijing, China, J. Geophys. Res., 124, 8065-8075, 2019. 
Borys, R. D. and Wetzel, M. A.: Storm Peak Laboratory: A Research, Teaching, and Service Facility for the Atmospheric Sciences, https://doi.org/10.1175/1520-0477(1997)078<2115:splart>2.0.co;2, 1997.

Boucher, O., Randall, D., Artaxo, P., and Bretherton, C.: Clouds and aerosols, 2013.

Connolly, P. J., Möhler, O., Field, P. R., Saathoff, H., Burgess, R., Choularton, T., and Gallagher, M.: Studies of heterogeneous freezing by three different desert dust samples, Atmos. Chem. Phys., 9, 2805-2824, 2009.

230 DeCarlo, P., Slowik, J., Worsnop, D., Davidovits, P., and Jimenez, J.: Particle Morphology and Density Characterization by Combined Mobility and Aerodynamic Diameter Measurements. Part 1: Theory, https://doi.org/10.1080/02786826.2004.10399461, 2004.

DeMott, P. J., Cziczo, D. J., Prenni, A. J., Murphy, D. M., Kreidenweis, S. M., Thomson, D. S., Borys, R., and Rogers, D. C.: Measurements of the concentration and composition of nuclei for cirrus formation, Proc. Natl. Acad. Sci. U. S. A., 100, 14655-14660, 2003.

DeMott, P. J., Prenni, A. J., Liu, X., Kreidenweis, S. M., Petters, M. D., Twohy, C. H., Richardson, M. S., Eidhammer, T., and Rogers, D. C.: Predicting global atmospheric ice nuclei distributions and their impacts on climate, Proc. Natl. Acad. Sci. U. S. A., 107, 11217-11222, 2010.

DeMott, P. J., Prenni, A. J., McMeeking, G. R., Sullivan, R. C., Petters, M. D., Tobo, Y., Niemand, M., Möhler, O., Snider, 240 J. R., Wang, Z., and Others: Integrating laboratory and field data to quantify the immersion freezing ice nucleation activity of mineral dust particles, Atmos. Chem. Phys., 15, 393-409, 2015.

DeMott, P. J., Hill, T. C. J., Petters, M. D., Bertram, A. K., Tobo, Y., Mason, R. H., Suski, K. J., McCluskey, C. S., Levin, E. J. T., Schill, G. P., and Others: Comparative measurements of ambient atmospheric concentrations of ice nucleating particles using multiple immersion freezing methods and a continuous flow diffusion chamber, Atmos. Chem. Phys., 17, 11227$11245,2017$.

Draxler, R. R. and Hess, G. D.: Description of the HYSPLIT4 modeling system, 1997.

Draxler, R. R. and Hess, G. D.: An overview of the HYSPLIT_4 modelling system for trajectories, Aust. Meteorol. Mag., 47, 295-308, 1998.

Garimella, S., Kristensen, T. B., Ignatius, K., Welti, A., Voigtländer, J., Kulkarni, G. R., Sagan, F., Kok, G. L., Dorsey, J., 250 Nichman, L., Rothenberg, D. A., Rösch, M., Kirchgäßner, A. C. R., Ladkin, R., Wex, H., Wilson, T. W., Ladino, L. A., Abbatt, J. P. D., Stetzer, O., Lohmann, U., Stratmann, F., and Cziczo, D. J.: The SPectrometer for Ice Nuclei (SPIN): an instrument to investigate ice nucleation, https://doi.org/10.5194/amt-9-2781-2016, 2016.

Hallar, A. G., Gannet Hallar, A., Chirokova, G., McCubbin, I., Painter, T. H., Wiedinmyer, C., and Dodson, C.: Atmospheric bioaerosols transported via dust storms in the western United States, https://doi.org/10.1029/2011g1048166, 2011.

255 Hallar, A. G., Petersen, R., Mccubbin, I. B., Lowenthal, D., Lee, S., Andrews, E., and Yu, F.: Climatology of New Particle Formation and Corresponding Precursors at Storm Peak Laboratory, 16, 816-826, 2016.

Kline, D. B.: EVIDENCE OF GEOGRAPHICAL DIFFERENCES IN ICE NUCLEI CONCENTRATIONS, Mon. Weather Rev., 91, 681-686, 1963.

Lacher, L., DeMott, P. J., Levin, E. J. T., Suski, K. J., Boose, Y., Zipori, A., Herrmann, E., Bukowiecki, N., Steinbacher, M., 260 Gute, E., Abbatt, J. P. D., Lohmann, U., and Kanji, Z. A.: Background free-tropospheric ice nucleating particle concentrations at mixed-phase cloud conditions, J. Geophys. Res., 123, 10,506-10,525, 2018. 
Levin, E. J. T., DeMott, P. J., Suski, K. J., Boose, Y., Hill, T. C. J., McCluskey, C. S., Schill, G. P., Rocci, K., Al-Mashat, H., Kristensen, L. J., Cornwell, G., Prather, K., Tomlinson, J., Mei, F., Hubbe, J., Pekour, M., Sullivan, R., Leung, L. R., and Kreidenweis, S. M.: Characteristics of ice nucleating particles in and around California winter storms, J. Geophys. Res., 124, $11530-11551,2019$.

McCluskey, C. S., Ovadnevaite, J., Rinaldi, M., Atkinson, J., Belosi, F., Ceburnis, D., Marullo, S., Hill, T. C. J., Lohmann, U., Kanji, Z. A., O'Dowd, C., Kreidenweis, S. M., and DeMott, P. J.: Marine and Terrestrial Organic Ice-Nucleating Particles in Pristine Marine to Continentally Influenced Northeast Atlantic Air Masses, J. Geophys. Res. Atmos. , https://doi.org/10.1029/2017jd028033, 2018.

MesoWest, https://mesowest.utah.edu/, last access: 12 January, 2022.

Müller, W.: Influence of different meteorological conditions on the concentration of freezing nuclei, 18, 55, 1969a.

Müller, W.: Über den Einfluß meteorologischer Bedingungen auf die Gefrierkerndichte der Luft, Arch. Met. Geoph. Biokl. A., 18, 55-74, 1969b.

Murray, B. J., O'Sullivan, D., Atkinson, J. D., and Webb, M. E.: Ice nucleation by particles immersed in supercooled cloud droplets, Chem. Soc. Rev., 41, 6519-6554, 2012.

Ng, N. L., Herndon, S. C., Trimborn, A., Canagaratna, M. R., Croteau, P. L., Onasch, T. B., Sueper, D., Worsnop, D. R., Zhang, Q., Sun, Y. L., and Jayne, J. T.: An Aerosol Chemical Speciation Monitor (ACSM) for Routine Monitoring of the Composition and Mass Concentrations of Ambient Aerosol, Aerosol Sci. Technol., 45, 780-794, 2011.

Niemand, M., Möhler, O., Vogel, B., Vogel, H., Hoose, C., Connolly, P., Klein, H., Bingemer, H., DeMott, P., Skrotzki, J., and Leisner, T.: A Particle-Surface-Area-Based Parameterization of Immersion Freezing on Desert Dust Particles, J. Atmos. Sci., 69, 3077-3092, 2012.

Obrist, D., Hallar, A. G., McCubbin, I., Stephens, B. B., and Rahn, T.: Atmospheric mercury concentrations at Storm Peak Laboratory in the Rocky Mountains: Evidence for long-range transport from Asia, boundary layer contributions, and plant mercury uptake, Atmos. Environ., 42, 7579-7589, 2008.

285 Petersen, R. C., Hallar, A. G., McCubbin, I. B., Ogren, J. A., Andrews, E., Lowenthal, D., Gorder, R., Purcell, R., Sleeth, D., and Novosselov, I.: Numerical, wind-tunnel, and atmospheric evaluation of a turbulent ground-based inlet sampling system, Aerosol Sci. Technol., 53, 712-727, 2019.

Richardson, M. S., DeMott, P. J., Kreidenweis, S. M., Cziczo, D. J., Dunlea, E. J., Jimenez, J. L., Thomson, D. S., Ashbaugh, L. L., Borys, R. D., Westphal, D. L., Casuccio, G. S., and Lersch, T. L.: Measurements of heterogeneous ice 290 nuclei in the western United States in springtime and their relation to aerosol characteristics, J. Geophys. Res., 112, https://doi.org/10.1029/2006jd007500, 2007.

Rogers, D. C., DeMott, P. J., Kreidenweis, S. M., and Chen, Y.: A Continuous-Flow Diffusion Chamber for Airborne Measurements of Ice Nuclei, https://doi.org/10.1175/1520-0426(2001)018<0725:acfdcf $>2.0 . c 0 ; 2,2001$.

Rolph, G., Stein, A., and Stunder, B.: Real-time Environmental Applications and Display sYstem: READY, 95, 210-228, 2017.

Schneider, J., Höhler, K., Heikkilä, P., Keskinen, J., Bertozzi, B., Bogert, P., Schorr, T., Umo, N. S., Vogel, F., Brasseur, Z., and Others: The seasonal cycle of ice-nucleating particles linked to the abundance of biogenic aerosol in boreal forests, Atmos. Chem. Phys., 21, 3899-3918, 2021. 
https://doi.org/10.5194/acp-2022-29

Preprint. Discussion started: 3 February 2022

(c) Author(s) 2022. CC BY 4.0 License.

(c) (1)

Schrod, J., Kleinhenz, D., Hörhold, M., Erhardt, T., Richter, S., Wilhelms, F., Fischer, H., Ebert, M., Twarloh, B., Della

300 Lunga, D., and Others: Ice-nucleating particle concentrations of the past: insights from a 600-year-old Greenland ice core, Atmos. Chem. Phys., 20, 12459-12482, 2020a.

Schrod, J., Thomson, E. S., Weber, D., Kossmann, J., Pöhlker, C., Saturno, J., Ditas, F., Artaxo, P., Clouard, V., Saurel, J.M., and Others: Long-term deposition and condensation ice-nucleating particle measurements from four stations across the globe, Atmos. Chem. Phys., 20, 15983-16006, 2020 b.

305 Soulage, G.: Counting and electron microscope study of European ice nuclei, 1966.

Steamboat Springs, CO (057936), https://wrcc.dri.edu/cgi-bin/cliMAIN.pl?co7936, last access: 12 January, 2022.

Stein, A. F., Draxler, R. R., Rolph, G. D., Stunder, B. J. B., Cohen, M. D., and Ngan, F.: NOAA's HYSPLIT atmospheric transport and dispersion modeling system, Bull. Am. Meteorol. Soc., 96, 2059-2077, 2015.

Ullrich, R., Hoose, C., Möhler, O., Niemand, M., Wagner, R., Höhler, K., Hiranuma, N., Saathoff, H., and Leisner, T.: A

310 New Ice Nucleation Active Site Parameterization for Desert Dust and Soot, J. Atmos. Sci., 74, 699-717, 2017.

U.S. Drought Monitor, https://droughtmonitor.unl.edu/Maps/MapArchive.aspx, last access: 12 January 2022. 
https://doi.org/10.5194/acp-2022-29

Preprint. Discussion started: 3 February 2022

(c) Author(s) 2022. CC BY 4.0 License.

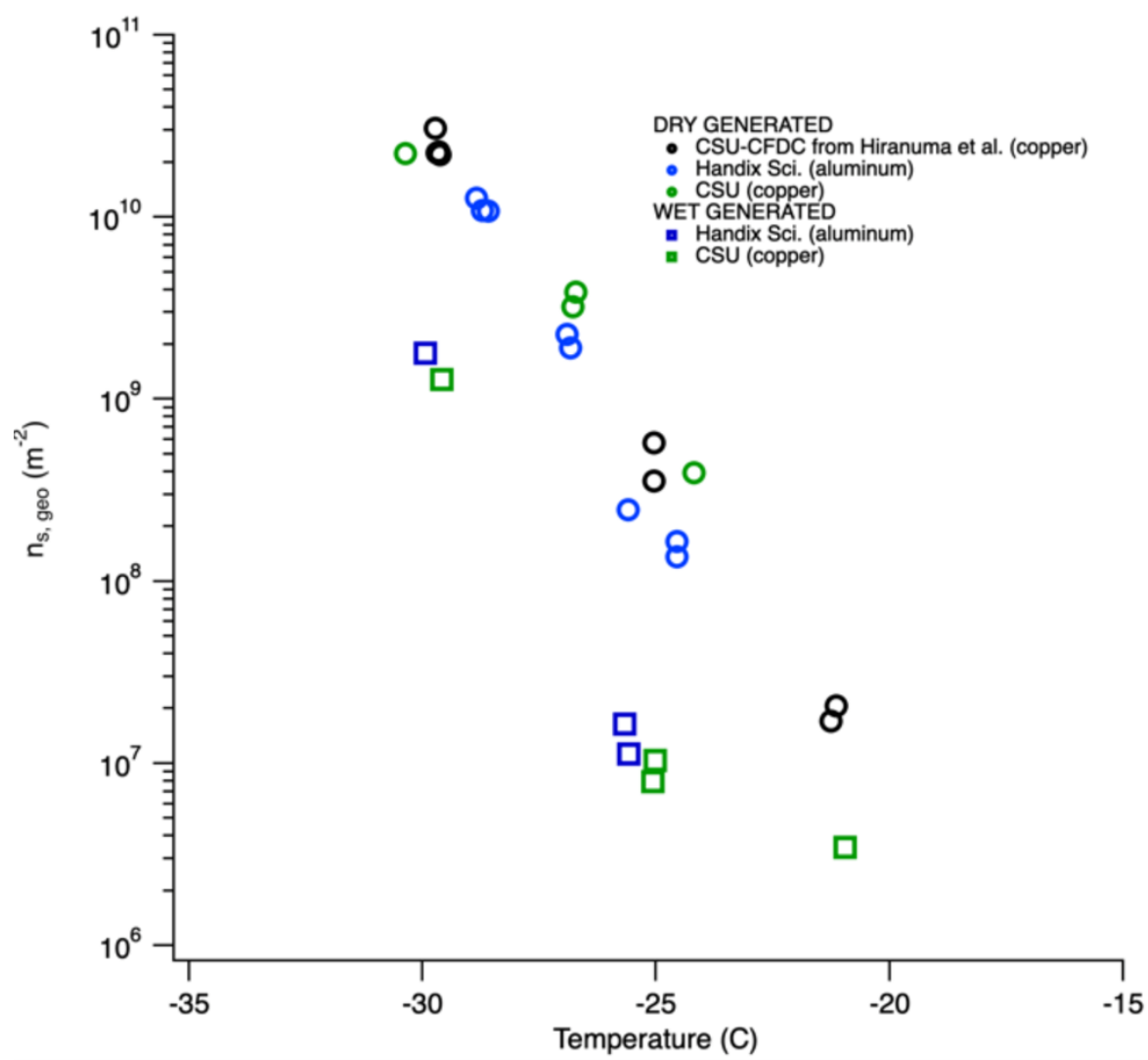

Figure 1: Active site density (ns) calculated for $500 \mathrm{~nm}$ illite particles generated using a nebulizer (wet; squares) or dry (circles) from CFDC measurements. Green points show measurements made with the CSU CFDC, which uses a copper column, blue points indicate data from the aluminum column CFDC-IAS. Black points show literature data from the CSU CFDC. 

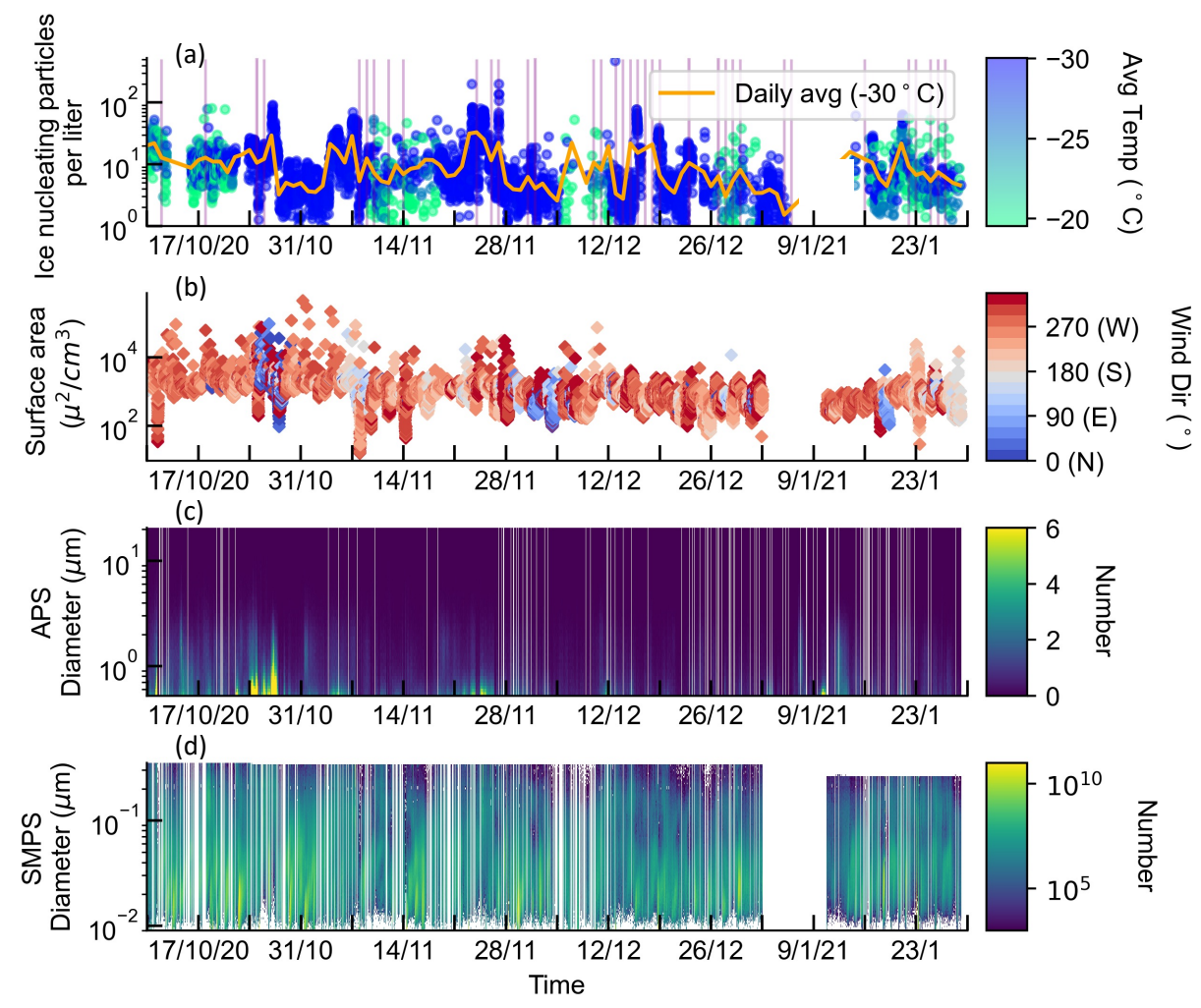

Figure 2. (a) Time series of ice nucleating particles (INP) colored by the average temperature of the CFDC observed at Storm Peak Laboratory (SPL) between October 2020-January 2021 (MST) and daily average INP at $-30 \mathrm{C}^{\circ}$ (orange line). Precipitation event days are marked with purple horizontal lines. (b) Calculated particle surface area between $10 \mathrm{~nm}-2.5 \mu \mathrm{m}$, colored by wind direction in degrees, where $0^{\circ}$ is north and $270^{\circ}$ is west. The wind direction is discretized by cardinal direction. (c) Time series of hourly aerodynamic particle sizer (APS) data observed at SPL. (d) Time series of hourly scanning mobility particle sizer (SMPS) data observed at SPL for the same time period. 

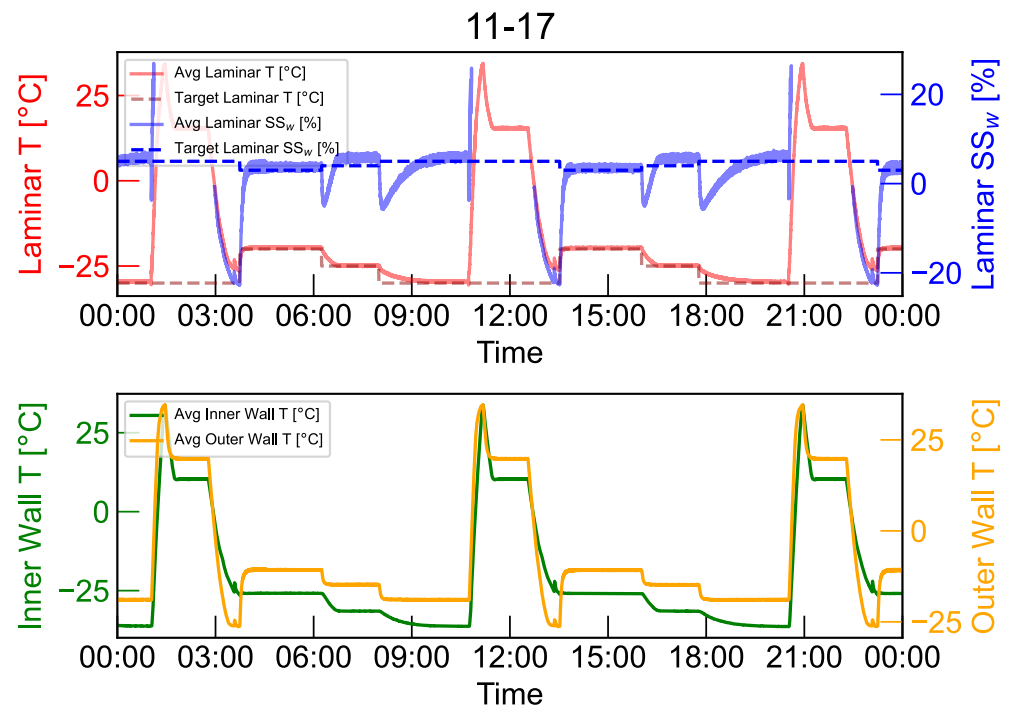

Figure 3. Example of CFDC-IAS operating conditions for November 17, 2020, in local time (MST). (Top) Target and average laminar temperatures in $C$ (left axis) and target and average water supersaturations in \% (right axis). (Bottom) Average inner wall temperature (left axis) and outer wall temperature (right axis) in $\mathrm{C}$. 

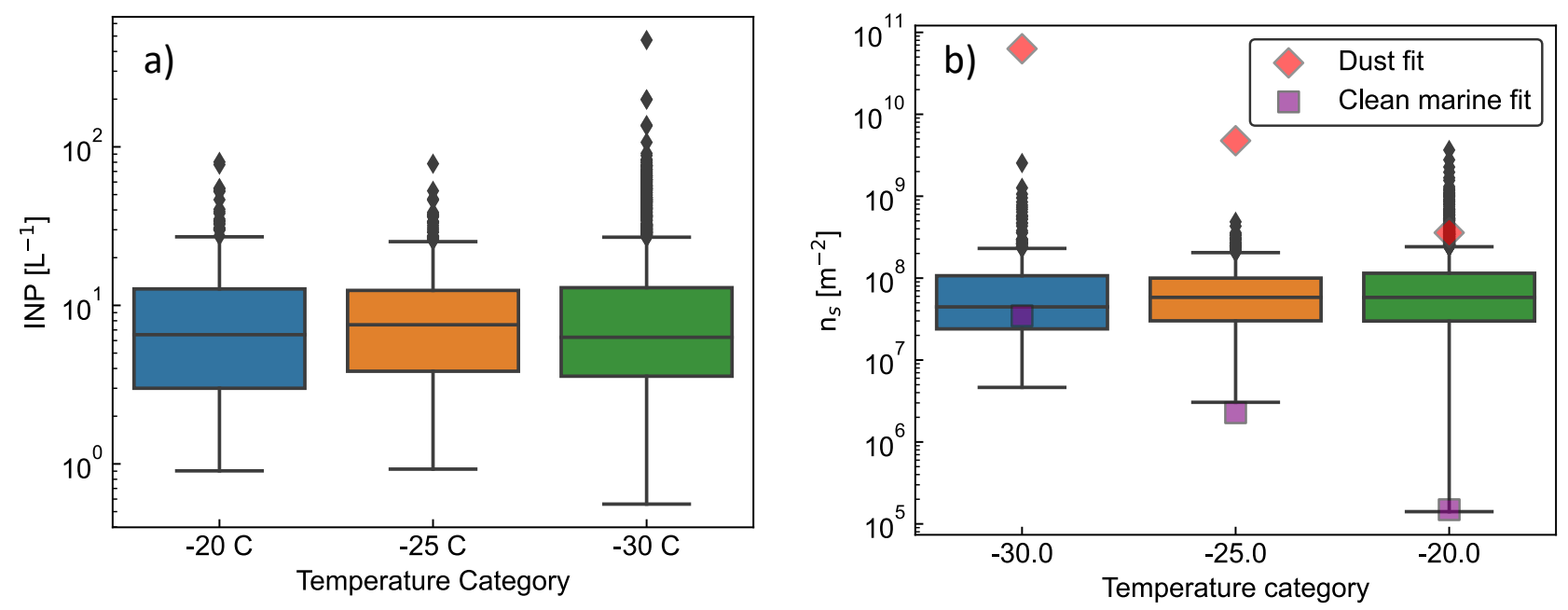

Figure 4. a) All statistically significant INP observed at Storm Peak Laboratory, by temperature range. b) Surface active site density, $\mathbf{n}_{\mathrm{s}}$, using aerosol surface area from the SMPS and APS. The dust fit is from Ullrich et al., (2017) (their equation 5) and the clean marine fit is from McCluskey et al. (2018) (outlined in their Sect. 3.5). 
https://doi.org/10.5194/acp-2022-29

Preprint. Discussion started: 3 February 2022

(c) Author(s) 2022. CC BY 4.0 License.
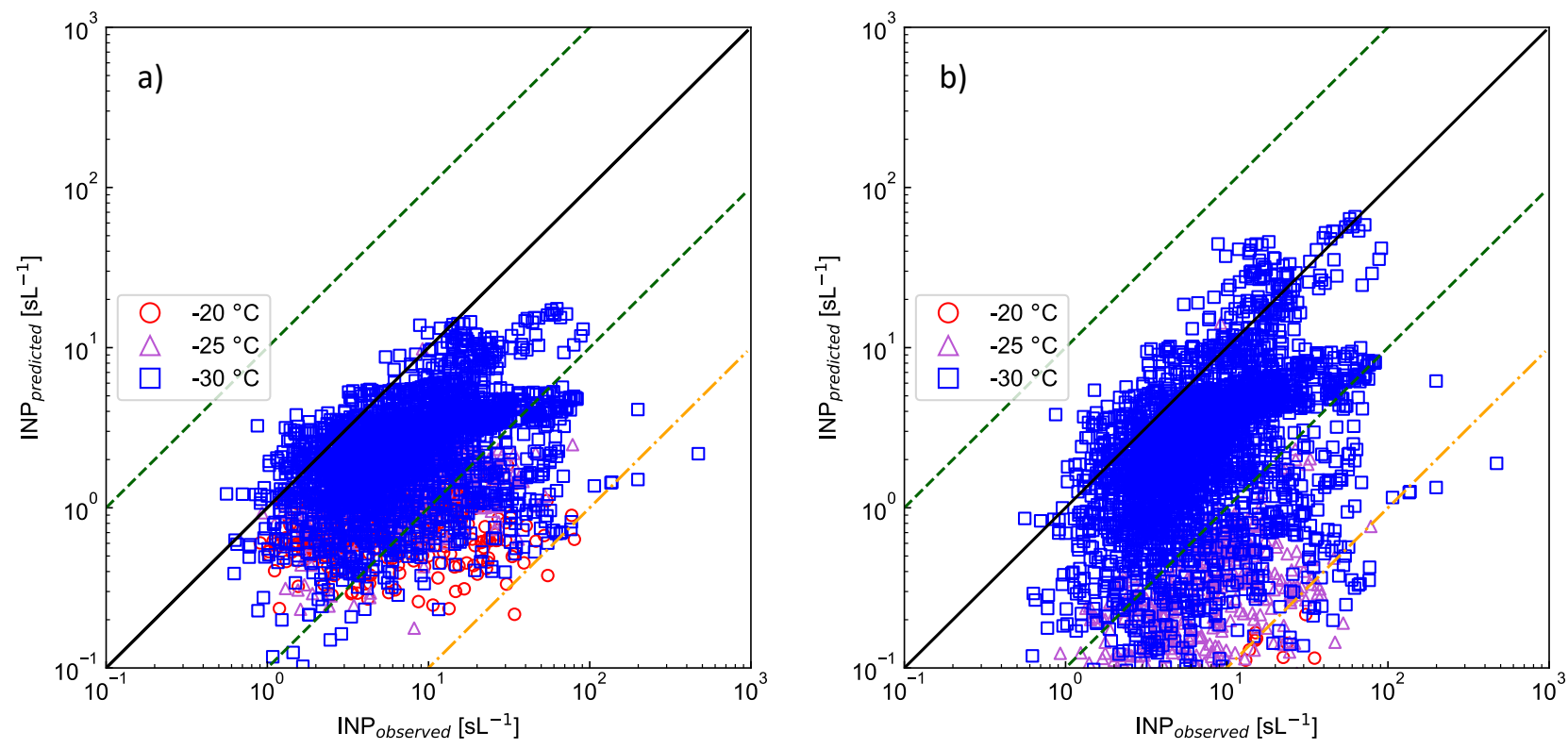

360 Figure 5. a) The "D10" (Demott et al., 2010) parameterization. b) The "D15" (Demott et al., 2015) parameterization. The black solid lines on both subplots are the 1-to-1 line, the green dashed lines are the 1-to-10 and 10-to-1 lines, and the orange dashed lines are the 1-to-100 lines. 